\title{
FRETTING-FATIGUE ANALYSIS OF SHOT-PEENED ALUMINIUM AND TITANIUM TEST SPECIMENS
}

\author{
Sabrina Vantadori ${ }^{1}$ and Andrea Zanichelli ${ }^{2}$ \\ ${ }^{1}$ University of Parma \\ ${ }^{2}$ Affiliation not available
}

August 7, 2020

\begin{abstract}
In last decades, many alleviation measures were proposed in order to improve the life of fretting fatigue affected components. The aim of such palliatives is that to counteract the high stress gradients that arise near the contact surface. In such a context, the shot peening treatment is worth noting. Therefore, in the present paper, the fatigue life of shot-peened aluminium and titanium alloy specimens, subject to fretting fatigue under partial slip regime, is assessed by means of the Carpinteri et al. criterion for fretting fatigue. Firstly, according to the superposition principle, the relaxed residual stresses (due to the shot peening treatment) are combined with the stress components due to fretting fatigue loading. Then fretting fatigue assessment is performed. In such a context, a novel theoretical law for the relaxed residual stress field is here proposed, the implementation of which shows very promising results in terms of fatigue life estimation of the shot-peened specimens examined.
\end{abstract}

\section{Hosted file}

FFEMS - Vantadori et al. - Text - v10.docx available at https://authorea.com/users/349430/ articles/474536-fretting-fatigue-analysis-of-shot-peened-aluminium-and-titanium-testspecimens

\section{Hosted file}

FFEMS - Vantadori et al. - Figures and Tables - v5.doc available at https://authorea.com/ users/349430/articles/474536-fretting-fatigue-analysis-of-shot-peened-aluminium-andtitanium-test-specimens 